\title{
Artikel
}

Issue

Issue / Series / Title

PsychoPraktijk

Issue / Series / Volume Nr

2

Issue / Date

2015

Issue / Pages / First Page

Issue / Pages / Last Page

\section{Tonen van dankbaarheid: een nieuw therapeutisch hulpmiddel?}

door Caroline Braet

Mensen die depressief zijn hebben niet alleen gevoelens van somberheid en negatieve affectiviteit, maar ook weinig gevoelens van positieve affectiviteit. Hoewel cognitief-gedragstherapeutische behandelprogramma's hierop adequaat inwerken, worden er nog steeds nieuwe methodieken geëvalueerd met een meerwaarde voor de behandeling. Eén methodiek die aan belang wint en specifiek zou inwerken op het verhogen van positieve affectiviteit, is het tonen van dankbaarheid, 'expressing gratitude' genaamd.

Er is de laatste tien jaar in de psychologieliteratuur heel wat geschreven over 'dankbaarheid tonen' waarbij de volgende vragen worden gesteld:
a. kun je de mate waarin iemand dankbaarheid vertoont meten?
b. is het vertonen van dankbaarheid een persoonlijkheidskenmerk?
c. is het mogelijk het niveau van dankbaarheid te verhogen?
d. kan men door het oefenen van dankbaarheid het welbevinden verhogen? 
e. zijn er factoren die dit leerproces positief beïnvloeden?

Op elk van deze vragen zal ik hieronder nader ingaan.

\section{Kun je dankbaarheid meten?}

$\mathrm{Al}$ in 2002 werd door McCullough e. $\mathrm{a}^{1}$ een onderbouwd artikel geschreven over 'gratitude'. Daarbij rapporteren ze ook over een kleine schaal 'The Gratitude Questionnaire'. De schaal bestaat uit zes items en voor elke uitspraak scoort de invuller op een schaal van 1 tot 7 in welke mate hij/zij met de uitspraak sterk akkoord (7) dan wel helemaal niet akkoord (1) gaat (zie kader 1).

\section{Kader 1 'The Gratitude Questionnaire’.}

\section{Vragen}

1. Ik heb zoveel in leven waar ik dankbaar voor ben.

2. Wanneer ik een lijst zou maken waarop alles staat waar ik dankbaar voor ben, zou het een lange lijst zijn.

3. Wanneer ik naar de wereld kijk dan is er niet veel om dankbaar over te zijn

4. Ik ben dankbaar tegenover heel veel mensen.

5. Naarmate ik ouder word, ben ik meer in staat de mensen, gebeurtenissen en situaties te appreciëren die deel zijn geworden van mijn persoonlijke geschiedenis.

6. Er moet een lange periode voorbij gaan voordat ik dankbaar kan zij naar iets of iemand.

Instructie: Geef aan in welke mate je met elk van deze uitspraken sterk akkoord (7), akkoord (6), licht akkoord (5) dan wel neutraal (4), licht niet akkoord (3), niet akkoord (2) dan wel helemaal niet akkoord (1) gaat.

Scoring: De scoring voor item 3 en 6 wordt omgekeerd. Nadien worden de scores voor de zes items opgeteld. De totaal score zal dan variëren tussen minimum 7 en maximum 42. Alhoewel er geen echte normen zijn, toont een studie van Harbaugh \& Vasey $^{2}$ aan dat men bij studenten een gemiddelde score van $\mathrm{x}=36$ vond.

\section{Is dankbaarheid een persoonlijkheidskenmerk?}

$\mathrm{Er}$ is nog steeds discussie over de vraag of dankbaarheid tonen een aangeboren persoonlijkheidskenmerk is dan wel verworven is. Sterker nog, er is zelfs discussie over de vraag of het een gunstig dan wel ongunstige eigenschap is. $\mathrm{Al}$ in de oudheid waren filosofen zoals Aristoteles 
en Epicurus geboeid door deze eigenschap, maar men kwam er niet uit of het tonen van dankbaarheid nu gunstig was voor het welzijn of niet.

In de conceptpaper van McCullough e.a. ${ }^{1}$ wordt onderscheid gemaakt tussen dagelijkse gevoelens die komen en gaan enerzijds versus persoonlijkheidskenmerken die redelijk stabiel zijn en waarbij positieve affectiviteit er één van is. De auteurs argumenteren dat het tonen van dankbaarheid beide kan zijn, maar dat er toch argumenten zijn om dit concept als een persoonlijkheidstrek te zien. Dit wordt dan als volgt gedefinieerd: 'Het is de algemene tendens dankbaarheid te herkennen en te reageren met dankbaarheid op de goedheid van anderen binnen de positieve ervaringen die men meemaakt. Ze tonen ook aan dat naarmate men hoger scoort op dit kenmerk, men minder materialistisch is ingesteld, een hogere levenssatisfactie vertoont én een hoger niveau van prosociaal gedrag vertoont. Er zijn positieve associaties aangetoond (maar ze vallen er niet mee samen) met de Big-5

persoonlijkheidsfactoren zoals aangenaamheid, extraversie, openheid en nauwgezetheid. Naarmate men hoger scoort op het persoonlijkheidskenmerk (zie ook kader 1) zou men positieve gevoelens van dankbaarheid intenser en frequenter ervaren, zelfs meerdere keren per dag. Ook de range van zaken (baan, gezondheid, familie, levensomstandigheden) waarvoor men dankbaarheid voelt is ruimer bij mensen met een hoge score voor deze persoonlijkheidstrek. Vraagt men aan mensen aan wie ze iets te danken hebben dan merk je dat hoge scorers op 'dankbaarheid' ook steeds meerdere mensen zullen opsommen, in vergelijking met lage scorers.

\section{Is het niveau van dankbaarheid te verhogen?}

Een recente studie van Harbaugh \& Vasey ${ }^{2}$ beschrijft hoe een groep studenten met hoge en lage scores op depressie de opdracht kreeg gedurende veertien dagen elke dag een online dagboekje in te vullen waarbij ze niet alleen hun stemming invulden, maar ook de opdracht kregen een 'dankbaarheidsoefening' te doen (zie kader 2). De manipulatie lukte. Het bleek ook een haalbare opdracht te zijn: zowat $85 \%$ van de deelnemers slaagde er in dit dertien van de veertien dagen vol te houden.

\section{Kader 2: 'Gratitude Exercises'}

Ik wil je vragen de komende veertien dagen elke avond even tijd vrij te maken om kort stil te staan bij datgene wat je dankbaar maakt. Elke avond kun je vijf dingen invullen in je dagboek. Dit kunnen zaken zijn die je gedurende de dag meegemaakt hebt (bijvoorbeeld iets lekkers gegeten), dingen die je opgemerkt hebt (bijvoorbeeld dat het weer een meevaller is), of meer abstracte zaken waaraan je denkt als je je leven bekijkt (bijvoorbeeld dat je een liefhebbende familie hebt). Het maakt niet uit wat het is, als het je dankbaar maakt kun je het noteren. Noteer ook telkens op een schaal in welke mate het je dankbaar maakt.

\section{Dagboek}

Vul in voor vandaag: geef vijf dingen, situaties, personen op waarvoor je je vandaag dankbaar voelt en in welke mate:

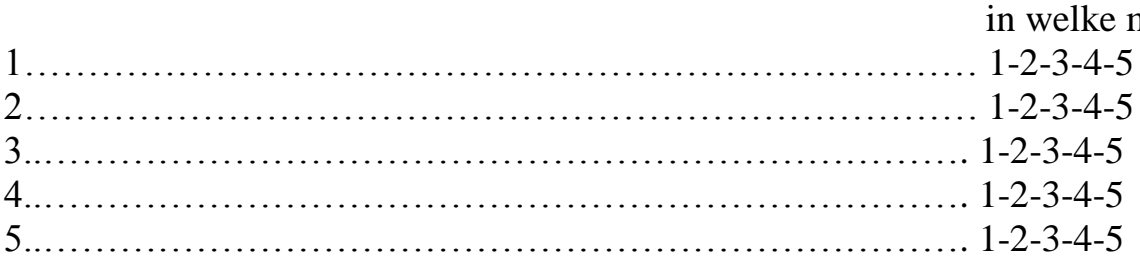


Er zijn ook varianten beschreven van 'dankbaarheidsoefeningen' in de literatuur. Bijvoorbeeld: een brief schrijven naar iemand die je apprecieert (zonder te verzenden), waarbij je aangeeft waarom je die persoon dankbaar bent.

\section{Kan oefenen het welbevinden verhogen?}

Het dagelijks oefenen met het tonen van dankbaarheid zou ertoe leiden dat we onze aandacht meer op het positieve richten, waardoor we meer kans maken positieve herstructureringen te doen en tekorten in positieve affectiviteit bestrijden.

De oefeningen werken niet voor iedereen even goed. Hierover moet nog verder onderzoek gebeuren. Zoals kon verwacht worden werken de oefeningen beter naarmate iemand (a) vooraf weinig dankbaarheid vertoonde (b) hoog scoorde voor depressieve gevoelens.

\section{Welke positieve factoren zijn er?}

Factoren die men tot hiertoe onderzocht zijn non-specifieke karakteristieken die in meerdere behandelingen een aantoonbare meerwaarde hebben zoals: (a) de mate waarin men moeite doet de oefeningen goed te doen en (b) de mate waarin men een goede rationale krijgt betreffende waarom men die oefeningen goed moet doen (zie kader 3). Harbaugh \& Vasey ${ }^{2}$ onderzocht dit ook, maar ze vonden enkele korte termijn effecten. Hun resultaten zijn dus op dit vlak nog niet overtuigend.

\section{Kader 3 Rationale bij 'Gratitude Exercises'}

Het ligt niet echt in onze menselijke natuur aandacht te geven aan dingen waarvoor we dankbaar zijn. Toch wijst onderzoek uit dat het appreciëren van deze zaken ons niveau van welzijn kan verhogen. Dit komt omdat denken aan dingen waarvoor we dankbaar zijn ons een goed gevoel geeft en deze goede gevoelens kunnen een tijdlang doorwerken. In zo'n stemming staan we steeds meer open voor andere positieve zaken in ons leven die we misschien ervoor niet hadden opgemerkt en gaan we meer zaken positief interpreteren.

\section{Conclusie}

Depressieve mensen de opdracht geven dagelijks vijf zaken op te noemen waarvoor ze dankbaar kunnen zijn, lijkt een effectieve methodiek met een goede impact op het welzijn. Het evalueren van deze methodiek in een gecontroleerde omgeving is een goede zaak. Dit zou men ook met andere emotieregulatiemethodieken kunnen doen. Zo zou men op dezelfde wijze participanten kunnen vragen twee weken lang elke dag een oefening te doen in 'mindful accepteren', 'zelf-compassie' en 'positieve herstructurering' en dan telkens nagaan of het gebruik van die ene methodiek (tegenover een controlegroep) aangeleerd kan worden en effectief is op korte en langere termijn.

Er is nog verder onderzoek nodig naar de lange termijn effecten, de effecten op gezondheid, de moderatoren (zoals een goede rationale), die het leerproces kunnen bevorderen. Ook naar het onderliggende werkingsmechanisme is nog onderzoek nodig. Zo stelt men zich alsnog de vraag: klopt het dat depressieve mensen die meer dankbaarheid vertonen een hoger niveau van welzijn ontwikkelen omdat ze meer oog hebben voor het positieve in hun leven of is dat omdat ze zich nu meer positieve zaken kunnen herinneren? Anderen vragen naar de conceptafbakening en vooral het precieze verschil tussen dankbaarheid en gelukkig-zijn of optimisme. 


\section{Literatuur}

1. McCullough, M.E. e.a. (2002). The grateful disposition: a conceptual and empirical topography. Journal of personality and social psychology 82: 112-127.

2. Harbaugh, C.N. \& Vasey, M.W. (2014). When do people benefit from gratitude practice? Journal of positive psychology 9: 535-546.

Prof. dr. C. Braet is verbonden aan de Universiteit Gent, Vakgroep Ontwikkelings-, Persoonlijkheidsen Sociale Psychologie (Caroline.Braet@UGent.be). 